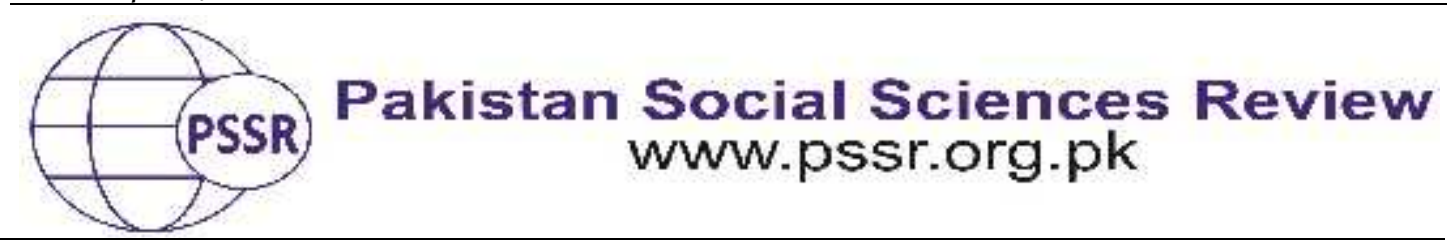

RESEARCH PAPER

\title{
Abandoned and Destitute: A Case Study of Divorced Women Residing in a Welfare Complex in Pakistan
}

\author{
Dr. Aisha Anees Malik ${ }^{1}$ TanzilaSaba² Dr. Saadia Abid ${ }^{3}$
}

1. Assistant Professor, Centre of Excellence in Gender Studies, Quaid-i-Azam University, Islamabad, Pakistan

2. Research Scholar, Department of Anthropology, Quaid-i-Azam University, Islamabad, Pakistan

3. Assistant Professor, Department of Anthropology, Quaid-i-Azam University, Islamabad, Pakistan

\begin{tabular}{|c|c|}
\hline PAPER INFO & ABSTRACT \\
\hline Rece & \multirow{12}{*}{$\begin{array}{l}\text { This paper investigates the implications of divorce for women. } \\
\text { Using in-depth interviews, observation and participant } \\
\text { observation, it generates rich qualitative data that sheds light on } \\
\text { the reasons for divorce and its consequences for women. The } \\
\text { locale of the study is a government run social welfare complex in } \\
\text { Rawalpindi, Pakistan. It highlights how there is no ideal type } \\
\text { marital arrangement that can guarantee conjugal happiness. In } \\
\text { addition, loss of job, moral lewdness of men as well as } \\
\text { interference of relatives and the lack of a dowry can cause } \\
\text { marriages to break-up. The consequences of divorce for women } \\
\text { range from emotional stress and psychological problems to the } \\
\text { loss of social as well as financial status. But the worst } \\
\text { consequence is rejection by husband and abandonment by the } \\
\text { natal family, extended relatives and friends. Destitute and } \\
\text { abandoned, these women have nowhere to turn and end up in } \\
\text { shelter homes. }\end{array}$} \\
\hline $\mathrm{A}$ & \\
\hline A & \\
\hline 21 & \\
\hline Onli & \\
\hline $\begin{array}{l}\text { May } 10,2021 \\
\text { Keywords: }\end{array}$ & \\
\hline Abandoned, & \\
\hline & \\
\hline & \\
\hline *Corresponding & \\
\hline Aut & \\
\hline sabid@qau.edu.pk & \\
\hline
\end{tabular}

\section{Introduction}

This particular paper sets out to hear the voices of women on the social issue of divorce. Historically the standpoint of men has been consistently privileged and that of women devalued (Smith, 2005). This view was challenged by thefeminist standpoint theory which claims that knowledge is always rooted in a particular position and that women are privileged epistemologically by being members of an oppressed group and their perspective enables us to create a more objective account of the world (Harding, 2004). The paper then explores the reasons as well as the consequences a divorce from women's perspective. The paper concludes that the worst consequence of divorce is destitution exacerbated by abandonment by the consanguineous family which in turn exacerbates other harmful effects. It 
recommends investing in women's education that will make them employable thereby increasing their position in both private and public spheres.

\section{Literature Review}

Pakistan is a patriarchal society with women being subordinate to men in almost all social, political and economic spheres (Isran \& Isran, 2012). Family is a key patriarchal unit (Moghadam, 2004). Primarily conceived as biologically determined, the continuity and propagation of the family is made possible through the institution of the marriage. Pakistani families are not only patrilineal but also patrilocal where brides move to the husband's home aftermarriage where they are not only subordinate to all men but also senior female relatives of the husbands (Kandiyoti, 1998\&Muzaffar, et. Al. 2018). Largely economically inactive and depending upon their location and position within the social setup, women either do reproductive work, work as unpaid family members in the fields, or are absorbed in low paid work in the informal economy. The literacy rates of women are also quite dismal as compared to men (Saleemi, 2021). This leaves most women dependent on either their husbands, if married, or their fathers and brothers if unmarried. This means that both financial and social status of women is dependent upon their relationships with men. Any dent in these relationships has serious consequences for women in the form of a loss of social and financial status.

Legally and religiously permissible but culturally demonized, divorce is seen as a disruption causing chaos in the family life (Amato, 200), the focal institution of the society. Since in the traditional division of labour in a patriarchal society, women's role is assumed to be solely centred on reproductive and caring activities in the house, any such disruption is seen as their failure. Already in subordinate positions in a patriarchal society and economically, marginalized, they tend to bear the brunt of a breakdown in marriage. Loss of marriage should only translate into the breakup of the family that has come into existence through that legal act marriage. It, however, for many women also results in the loss of consanguineous family. They are abandoned by their consanguineous family as a punishment for failing to uphold the marital ties. If accepted back, they are treated poorly by their own kin and seen as a burden. The dominant idea that women's security lies in marriage and that they need to invest all energies in making the institution work, also then lays the blame of divorce on women.

\section{Material and Methods}

The main aim of the research was to investigate the social implications of divorce for women and children. The impact on children has been dealt with elsewhere. This paper in particular focuses on two main objectives: i) the reasons of divorce; ii) the consequences of divorce for women. The research was conducted in the Social Welfare Complex II situated in Shamsabad Rawalpindi, Pakistan. It is a government run provincial facility established under the Department of Social Welfare and Bait-ul-Maal, Punjab. 
For the purpose of the research, a purposive ample of divorced women residing in the Dar-ul-Aman (a shelter home for women within the complex) were selected. Research methods of interview, observation and participant observation were employed to generate qualitative date. Twenty three indepth and unstructured interviews of divorcedwomen were conducted. In addition, three key informant interviews were also obtained. Informal conversations while participating in many activities are also part of research methods. Ethnographic methods of observation and participant observation were important aspects of the research design and involved spending extensive time, morning till evening, for several days in Dar-UlAman and Kashana (a shelter home for children within the complex). In Dar-UlAman there were lawyers' sessions to attend with the respondents. In kashanacentre many functions were held to celebrate special occasions allowing for participant observation opportunities. In addition routine practices like watching TV, playing together in the ground, having lunch every day was very useful in not only developing rapport with the respondents but also generated data through informal conversations in their natural settings and observing their expression during interviews.

\section{Data Presentation}

A thematic analysis of data generated from the field yielded rich insight into the reasons as well as consequences of divorce. They have been presented in the following sub-sections.

\section{Reasons of Divorce}

Ramzan et al (2018) cited illiteracy as the major cause of divorce in Pakistan. The respondents of this study, however, gave a variety of reasons that can largely be termed as socio-cultural as well as economic and are categorised into themes highlighted below.

\section{Marital Arrangement}

The type of marital arrangement had a bearing upon the success or failure of marriage according to women. However no particular type could be singled out as the reason for divorce as women's experiences varied across all types of marital arrangement. Shazia was forced into an arranged marriage by her parents despite loving someone else. She says, "Behaviour of my ex-spouse and his family was nice with me but I couldn't forget my beloved and refused toadjust with him." It was not necessarily women who had been forced into marriages who get divorced. Shagufta had been married to a cousin by her parents who were in the Army. The husband refused to consummate the marriage and left her with his parents. He didn't visit them for months. After two years, the family found through a friend that he was already married and had 2 children. Since he was a first cousin, families on both sides insisted that she accept this marital arrangement. But she moved to the shelter home and applied for divorce. 
Women who had married for love did not fared any better. Naseem recounted how she had met her spouse and fallen in love with him before marriage. He worked in a hospital on a handsome salary and showered her with gifts. Their love affair continued for a year in secret and then they got married without the permission of parents. Her parents had already warned her that if she went ahead with the marriage, they wanted no contact with her. Naseem says, "after marriage the behaviour of my mother-in-law was so insolent because she had wanted her son to marry his cousin. She didn't allow me to touch even the things in her home.Mother-in-law also gave wrong information to her son about me."

The domestic politics of her mother-in-law destroyed her marital life.One day she went to the market for shopping with her mother-in-law's permission. When her spouse came home, his mother lied and said that Nasim went out of the house without her permission. She exaggerated by saying that Nasim did this often and spent hours outside. On Nasim's return, her spouse started quarrelling with her and also beat her. He suspected that she had gone out to meet someone else. This set in a series of events that escalated discord between them. Ultimately he stopped sleeping with her. Finally under pressure from the mother and under the influence of these suspicions about Nasim's character, he divorced her and agreed to marry his cousin.

WattaSatta or bridal exchange marriage is another form of marital arrangement that led to the divorce of Naila (age 35) residing in the shelter home. In some societies it was endogamous marriages are preferred. Bride exchange marriage involves the simultaneous marriage of a brother-sister pair from one family to a sister-brother pair in another family. Nails says, "My brother's spouse did not behave nicely with him or his parents. She wanted a separate home. I, on the other hand, was satisfied from my marriage and developed good relations with all. My brother's spouse demanded a divorce and in return my ex-spouse also divorced me."

Marriages contracted to settle disputes also have lesser chances of success. Nasreen was married off to a relative's son in settlement for a property dispute. They mistreated her from day one of the marriage. Refusing food, snatching away her jewellery, locking her up, and beating her were some of the things they did to her. Divorce seemed to be the only way out of that misery.

\section{Moral Lewdness of Men}

Sakeena's marriage ended in a divorce due to immoral habits of her husband. She claimed, "My ex-spouse indulged in immoral activities such as drinking and gambling etc. He spent his money in them and did not provide financial support to the family. He did not take the responsibility of the children." On top of this his bad companions often turned up at the house. People also came to the house to claim money he had lost and on not being paid created ruckus. He would take out his anger on her and become violent. He even tried to have her sleep with other men for 
money after falling through hard times despite the fact that she had two children. Her refusal to do so, led to her divorce.

\section{Joint Family System}

Joint family system is very common in Pakistani society. Ambreen blamed the problems created by living with extended family as the major reason for divorce. She tried to understand the norms of this family. Her mother-in-law always quarrelled with her, criticized her behaviour and dressing. She created bad feelings between Ambreen and her husband based on lies. She very possessive of her son and got upset when he gave Ambreen attention or money.Some respondents even blamed black magic, use of taweez (amulets) and other such modes employed by mothers in laws to turn husbands against wives. Wife beating was also blamed on such things.

\section{Marital Incompatibility}

Incompatibility due to class, age or education also was cited as causes for divorce. Marriage is often used for upward social mobility. But life for those marrying higher than them can be difficult. Safeena claims that her marriage failed because she was from a lower economic class than her husband. He had refused to marry a girl who belonged to upper class because he believed that a girl who belonged to a lower class would be well-behaved and obedient. But his parents wanted material benefits from the girl's family. After marriage they were very rude to her. In the beginning he was supportive of her and told her to ignore their behaviour. Later he met a friend who had married rich and often boasted of how his wife had financially helpedhim through a difficult time. Safeena's husband started having second thoughts about his decision and finally divorced her.

Difference in age was another factor causing marriages to break up. Raheela was 10 years older than her husband. Marrying cousins was a norm in their family. He married her reluctantly due to family pressure. The marriage didn't last long. Raheela blames the divorce on her husband's immaturity. After marriage he was often impolite and mocked her age. He was ashamed of being seen with her in public. He wouldn't respond to her display of affection even in private. He scoffed all her opinion, choices and ideas. Therefore they failed to develop good relationship.

Higher education of women than men was another barrier in marital harmony. Ayesha had a master in Islamic Studies and taught in a college. Her husband was uneducated with a blue coloured job. One out of five siblings, her parents was getting old and feared for their future. They felt that a spouse even if uneducated would be able to provide her security. Ayesha recalls, "I had different life style, interest and thoughts. My ex-spouse was not broad minded. He didn't like my social interaction. He didn't trust me.He wouldn't let me meet my friends or relatives thinking that they would look down upon him." Most social interactions 
left him agitated and quarrelsome as he thought that people insulted him for living off of his wife's earning.

\section{Son Preference and Infertility}

Nosheen's husband divorced her because she could not give him a son. She had four daughters and was a satisfied mother. Problems started after the birth of the $2^{\text {nd }}$ daughter. Mother-in-law was the first one to complain that they were expecting a boy. When she was expecting the third child, her mother in law literally ordered that it better be a boy this time. When she gave birth to a daughter again, her mother-in-law wept with grief. She wailed that all her son's possessions will pass on to strangers as he had no son. The behaviour of her spouse also changed after this. He started mistreating Nosheen and the daughters. After the $4^{\text {th heleft }}$ her saying that she was incapable of bearing a son.

Childlessness was another reason for divorce. Tasswar Bibi was divorced as she failed to bear a child. She tried medical treatment for her infertility for six months but that didn't work. On advice of a friend she also went to a saint who gave her a taweez for her and the spouse. She wore it for three months but nothing happened. Then she tried to convince her husband to adopt an orphan to which he did not agree. In the end he divorced her labelling her to be manhoos (ill-omened). As an infertile woman, she was not only treated poorly by her husband and in-laws but also by family and friends who thought that she would cast her ill-boding on their fertility too.

\section{Lack of a Dowry}

Shakeela did not bring any worthwhile dowry according to her in laws. Her father was a daily-wage labourer. During proposal negotiations, her in-laws to be gave her parents a list of things they expected in the dowry. The list included things such as a fridge, television, furniture, gold ornaments and cash. As her parents couldn't provide all this, the wedding was about to be called. The boy last minute announced that he would marry her without a dowry. His parents were against this decision but gave in upon the son's insistence.After the marriage the spouse treated her well but the mother in law kept saying that she had been shamed in front of her relatives to bring a bride without dowry. She created many difficulties for Shakeela and quarrelled and often verbally abused her. One day her mother-in-law went to attend the marriage ceremony of a relative. In this marriage bride's family gave expensive things in the dowry. When mother-in-law returnedshe started brainwashing her son. She wept at how other women in the marriage had mocked her for her daughter-in-law's lack of dowry. Mother and son decided to demand 2 lakh rupees in lieu of the dowry. They left her at her parents' home saying that they will only take her back if she brings the cash dowry. Her failure to secure the money led to her divorce. 


\section{Husband's Unemployment}

Husband's loss of job was another reason of divorce. Providing for a family is considered the primary role of the husband. Rubina narrated how her ex-husband though educated couldn't find a reasonable job. He did contractual job in a private company. The first few months of the marriage passed harmoniously. He would give her Rs. 400 per month for personal expenditure and the rest to his mother for running the household. Problems started when she gave birth to twin boys. About the same time her husband got fired from his job on charges of corruption. Upon failing to find another job, he started quarrelling with her. The in-laws blamed her for bring them bad luck. One day her son fainted but they had no money to pay for transportation to the hospital so she borrowed money from her friend. Doctors diagnosed typhoid. She had no more money for medicines. She asked her husband to arrange medicines and also pay back her friend buthe quarrelled with her and said that he couldn't afford the expenses of children and wanted to leave her. Her mother-in- law jumped in the argument and added fuel to fire by reminding him how she had brought bad luck upon them and instigated him to divorce her.

\section{Impact of Divorce on Women}

The consequences of divorce for women ranged from social to emotional and financial as discussed in the following thematic sub-sections.

\section{Social Rejection}

Post divorce women complained of ill-treatment and rejection by their own families. Most parents were against a divorce, even if were cognizant of the difficulties women faced in the marriage. Shagufta had gone to her parents with her three kids after her divorce. She had turned to their house as she thought of it as a safe place for herself and her children. The behaviour of her parents was unexpected for her because she had thought that her parents will not letthem suffer alone. Parents constantly complained of lack of income to provide food and shelter to them. They discouraged her from attending marriage ceremonies or other social events in the family. Her own brother didn't like her kids mixing with his. Her friends criticised her and largely blamedher for the entire situation. If she went visiting, married couples avoided her. In the end, her parents asked her to move out as they felt that she brought them dishonour.

\section{Financial Loss}

Most of the respondents were uneducated and had no proper source of income. Their families did not provide financial support to them. Mehreen faced many problems after divorce. Children also lived with her and she was their primary caregiver. She said, "After divorce family did not provide financial support to me. I started workingas a maid. I earned verylittle money therefore couldn't manage the house hold expenses." She feels that her husband's situation improved after the divorce as he was freed of his responsibilities whereas hers deteriorated. 
Nosheen was also abandoned by her parents with her four daughters after the divorce. Her husband didn't like his daughters, and even before the divorce hadn't borne their expenses. So there was no expectation of child custody or maintenance after the divorce. She went to her parent's home but they refused to provide financial support to her. For a while she tried to survive on her own in a rented house and earned money as a domestic worker in different homes. Her employers occasionally gave her food and clothes for the children. But her salary was insufficient for to pay for the rent, food, education and bills. Finally destitute and abandoned, she came in Dar-Ul-Amman with the kid.

\section{Loss of Social Status}

Shakeela complained of loss of social status after divorce. People thought that divorce wasagainst the norms of our society and hence disrespected divorced women. She opines, "Before divorce Parents, friends and relatives gave me respect and importance. My parents discussed all personal matters with me. After divorce they ignored me in all matters and didn't give me respect. It was difficult for me to live with parents like this. They believed that after marriage a woman should live with her spouse as an obedient spouse and also play her role as a good mother for children."

Her parents did not accept her after divorceas they were against it in the first place. Other people criticized her as well. One day she went to meet her friend. Her friend ignored her and only spoke to her for 15 minutes. She was very hurt when her friend asked her not to come to see her again here. The friend's spouse thought a divorced woman to be a bad influence and advised his wife to stay away from Shakeela.

She couldn't bear how her parents, relatives and friends degraded her. All family members celebrated special occasions by wearing new dresses. Her parents didn't buy any clothes for her and her children. Her parents wanted her to get married again but she had three daughters and knew nobody reasonable will marry divorced women with three children. Mistreated by her family she came to live in the Dar-Ul-Aman.

\section{Emotional Problems}

During research we came to know that women faced many emotional ups and downs that came with end of marital relationships and abandonment by their natal families. Most of them narrated how they had suffered emotional problems such as anger, guilt, depression, and feeling of isolation and even exhibited negative attitudes towards others. Shazia explained how the loss of a marriage meant that she had no one to share her feelings and emotions with. In a society where sexual urges can only be satisfied through marriage, a divorce also meant an end to a physical relationship. Some others respondents also shared how a partner was important for 
women. On stop of this they had no natal family to fall back on for emotional support.

Some of the women at the centre exhibited rude and aggressive behaviour. Sakeena explained this as a result of the bitterness surrounding divorce. She recounted, "Before divorce I didn't get angrywith others. I had lost the ability of patience and tolerance. I couldn't understand that what was right and wrong for me. I always quarrelled with others. I didn't like when my parents, friends and relatives gave me any advice and interfered in my life. I couldn't tolerate rude behaviour of family members, relatives and friends." After the divorce she felt many changes in her behaviour. She didn't communicate politely with others and saw everyone as her enemy. She had anger towards her ex-spouse because he had abandoned her. She constantly thought of her house where she had lived with her husband and children. When she thought the cruelty of her ex-spouse she would become aggressive and harm her own self. She even attempted suicide. She didn't wants to live in this society where men were considered more powerful and were absolved of all blame. She always quarrelled with her parents, friends and relatives. Sometimes she verbally abused her siblings. She felt that they faulted her for the divorce. She would even beat her children without any mistake. In this situation her parents told her to leave their home and go live in Dar-Ul-Amman. Other respondents felt sorry for her and hoped that her parents would forget her mistakes, forgive her and accept her and the kids back.

Guilt was another common emotional effect of divorce. Naila explained how after the divorce she felt guilty. She could not face the relatives and thought they would deride her and blame her for the entire situation. She says, "I couldn't adjust after divorce I felt guilty that it was wrong decision of divorce. My brother and his spouse didn't accept me. They thought that I will demand my share in their assets."

Depression was another common psychological effect of divorce. Ambreen explains, "I was not satisfied from this life, because I always worried about my future and also couldn't fulfil dreams and desires. I hadlost a spouse who was the partner of whole life."It was so shocking for her when ex-spouse gave her the divorce as she hadn't expected that. She had so many dreams and hopes of a marital life with her ex-spouse. He forgot of her love, care and feelings. He divorced her without any fault of hers.She had two children who lived with their father. She came in Dar-Ul-Aman. It was a very difficult situation for her as she had been separated from her children and ex-spouse. She missed her children. Her life was completely changed. With unfulfilled dreams and desires, dependent on others for basic needs, she was very unhappy at the centre. She didn't talk to her roommates or other members of this centre. Due to depression she slept too much. When she awoke she wept a lot and called out to her children.

Many women accepted that they had developed a quarrelsome attitude post the divorce which further aggravated their situation. Naseema explains, "I had lost the ability of patience and tolerance. I always quarrel and also didn't develop good relations with others. I lived separate from others and didn't share all problems with 
others." During interview it was observed that they even quarrelled with each other in the centre and like Naseema they accepted it. Naseema openly admitted that she always quarrel with others and sometimes even verbally abused them. She believed that this rude behaviour was the result of her divorce. She was warned many times by the head of the welfare complex, but she couldn't seem to control her anger. Due to her rude behaviour women didn't like to talk with her therefore she often sat alone in her room. Her current roommates constantly complained that they didn't want to live with her. She shared how before divorce she was a polite person. She attributed her current behaviour tothedifficulties she had faced after the divorce and the negative attitude of her parents, relatives and friends. She had expected support from them but they had let her down.

\section{Discussion and Analysis}

A survey conducted by the Gallup Pakistan (2010) shows that $48 \%$ of all Pakistanis believe that rate of divorce has increased in Pakistan. The survey goes on the present that, "Forty eight percent $(48 \%)$ believe that it is because of lack of patience, $33 \%$ believe that it is due to being away from the religion, $27 \%$ claimed that the increase in divorce rate in Pakistan has been caused by the impact of western culture, $12 \%$ blame women for giving preference to their career, and 9\% said that one of the reasons for divorce is when men stop taking interest in the marital relationship. The data reveals no significant difference except that a higher percentage of urbanites $(21 \%)$ than ruralites $(6 \%)$ blame women for taking more interest in their careers which causes marriages to break."

Not hugely diverging from the survey, this research found are dowry, son preference, domestic issues, infertility, arrange marriage, forced for sexual activities, bride exchange as major reasons for divorce. In arranged marriages, women and men may be interested in someone else. In love marriage, in-laws are not happy. In bride exchange marriages, the mistake of one couple destroys the life of two. Some people enter into marriages to take revenge from others. After marriage commit violence on women. Marriages with class differences, age or educational differences also find it difficult to adjust with each other.Domestic issues destroy the marital life of women. Mother-in-laws don't want to let go of their sons which is typical in a patriarchal society as this is how they secure their position within the family (Kandiyoti, 1988). Son preference is also the cause of a divorce. With no state welfare systems in place, sons are seen as support in old age. Therefore men remarry for a son. Infertility is biological and natural process. But women get blamed for being infertile. People have increasingly become materialistic and lack of dowries can also lead to marriages breaking up.

The consequences of divorce for women are dire and they include emotional, social and financial losses. Women need love, care and attention of their spouses. After divorce they can't fulfil their sexual needs as well as emotional needs. They can't express or share their feelings and emotions. They had many expectations and hopes with their spouses. But now it is the breakdown of their hopes, dreams and 
expectations. Their behaviour changes. They don't participate in social activities. They limit interaction with others as they feel that their friends and relatives don't give them respect. Therefore develop negative feelings towards their family members, friends and relatives. They have anger towards others. They always quarrel with others. Many of them suffer from depression. They feel shame and guilt that they no longer live with their spouses and claim that people don't give respect to those women who live without a husband.

Divorce is not only anemotionally stressful experience for these women but also affects their social and financial status.After divorce women need the support of family members, friends and relatives. They are unable to face the situation alone. In this difficult situation their family members, relatives and friends neither support them nor have any contact with them. They blame that these women as responsible for divorce and absolve the men of their part in the divorce. These women face financial problems. In our society it is the responsibility of men to beard all the expenses of family and spouses. Men are dominant figure in our society. After divorce women depend on parents for financial support. Their parents don't provide them financial support. Most women can't find work because they are illiterate or have no professional skill. Some of these have to care for their children as their exspouses don't take the responsibility. It is difficult for women that provide all facilities to the children. Therefore they are forced by their circumstances to live in the Dar-ul-Aman and send their children to the Kashana centre. Loss of marriage than above all leads to the loss of the consanguineous family and leaves them destitute and abandoned. These women then have nowhere to go except for such places as the shelter home.

\section{Conclusion and Recommendations}

This study highlights how the loss of marriage leads to the loss of the natal family as well. There can be multiple reasons for a divorce. But in all, women are to take the blame for the break-down of the marriage. The consequence of the divorce is dire for women entailing loss of social as well as financial status. In addition many suffer from emotional and psychological problems due to abandonment by their natal kin, extended family members, friends and colleagues. Since women are dependent on men they are related to forsocial standing and financial security loss of marriage signals a break in these relationships leaving women destitute and abandoned.Investing in women's education and training may overcome some of these problems. It has been seen that outside earnings increase women's bargaining position within the household leading to more equitable economic and social outcomes for them (Sen, 1987). Improved educational attainment of women will lead to better employment opportunities which in turn will result in increased bargaining power improving their position in the home of their husbands as well as in their natal families. 


\section{References}

Amato, P. (2000). The Consequence of Marriages of Divorce for Adults and Children. Journal of Marriage and Family, Volume 64, Number 2, pp. 1269-1287.

Gallup Pakistan (2010). Views on Divorce Rate in Pakistan, Gilani Poll conducted by Gallup Pakistan, the Pakistani affiliate of Gallup International Association

Harding, S. G. (2004). The feminist standpoint theory reader: Intellectual and political controversies. New York: Routledge.

Isran, S. \&Isran, M.A. (2012). Patriarchy and women in Pakistan: A critical analysis. Interdisciplinary Journal of Contemporary Research in Business, Volume 4, Issue 6, pp. 835-839.

Kandiyoti, D. (1988). Bargaining with patriarchy. Gender \& Society, Volume 2, Number, 3,pp. 274-290.

Moghadam, V. (2004). Patriarchy in Transition: Women and the changing family in the Middle East. Journal of Comparative Family Studies, Volume 35, Issue No 2, pp. 137-162.

Muzaffar, M.Yaseen, Z. \& Ahmad, A. (2018). Child Marriages in Pakistan: Causes and Consequences, Journal of Indian Studies, Vol 4 Issue 2, 195-207.

Ramzan, S., Akhtar, S., Shabbir, A., Zafar, M.A., \&Yousaf, H. (2018). Divorce status and its major reasons in Pakistan. Sociology and Anthropology, Volume 6, Number 4, pp. 386-39.

Saleemi, S. (2021). How illiteracy perpetuates oppression of Pakistani women. Development and Cooperation.https://www.dandc.eu/en/article/half-pakistans-womencannot-read-or-write-any-language

Sen, A. (1987). Gender and Cooperative Conflicts. InWIDER Working Papers Series, World Institute for Development Economic Research (UNU-WIDER https://www.wider.unu.edu/sites/default/files/WP18.pdf

Smith, D. E. (2005). Institutional ethnography: A sociology for people. Walnut Creek, CA: AltaMira Press. 